\title{
Prevalence of Agglutinating Antibodies to Sarcocystis neurona in Raccoons (Procyon lotor) From an Urban Area of Virginia
}

Author(s): Katie Hancock, Anne M. Zajac , Francois Elvinger , and David S. Lindsay

Source: Journal of Parasitology, 90(4):881-882. 2004.

Published By: American Society of Parasitologists

DOI: http://dx.doi.org/10.1645/GE-302R

URL: http://www.bioone.org/doi/full/10.1645/GE-302R

BioOne (www.bioone.org) is a nonprofit, online aggregation of core research in the biological, ecological, and environmental sciences. BioOne provides a sustainable online platform for over 170 journals and books published by nonprofit societies, associations, museums, institutions, and presses.

Your use of this PDF, the BioOne Web site, and all posted and associated content indicates your acceptance of BioOne's Terms of Use, available at www.bioone.org/page/terms_of_use.

Usage of BioOne content is strictly limited to personal, educational, and non-commercial use. Commercial inquiries or rights and permissions requests should be directed to the individual publisher as copyright holder. 


\footnotetext{
, D. J. Forrester, AND E. C. GReiner. 1987. Pathogenicity of Haemoproteus meleagridis (Haemosporina: Haemoproteidae) in experimentally infected domestic turkeys. Journal of Parasitology 74: $228-239$.

Diggs, C. L., AND A. G. Osler. 1969. Humoral immunity in rodent malaria. Estimation of parasitemia by electronic particle counting. Journal of Immunology 102: 292-297.

Di Ruberto, C., A. Dempster, S. Khan, and B. Jarra. 2002. Analysis of infected blood cell images using morphological operators. Image and Vision Computing 20: 133-146.

Fedynich, A. M., D. B. Pence, AND R. D. Godrey JR. 1995. Hematozoa in thin blood smears. Journal of Wildlife Diseases 31: 436-438.

Godfrey, R. D. JR., A. M. Fedynich, and D. B. Pence. 1987. Quantification of hematozoa in blood smears. Journal of Wildlife Diseases 23: $558-565$.
}

JARVI, S. I., J. J. Schultz, And C. T. Atkinson. 2002. PCR diagnostics underestimate the prevalence of avian malaria (Plasmodium relictum) in experimentally-infected passerines. Journal of Parasitology 88: $153-158$

McKenzie, F. E., And W. H. Bossert. 1997. The dynamics of Plasmodium falciparum blood-stage infection. Journal of Theoretical Biology 188: 127-140.

Merino, S., J. Moreno, J. J. Sanz, And E. Arriero. 2000. Are avian blood parasites pathogenic in the wild? A medication experiment in blue tits (Parus caeruleus). Proceedings of the Royal Society of London B 267: 2507-2510.

RASBAND, W. 2002. ImageJ [PC program], version 1.25s. National Institutes of Health, Bethesda, Maryland.

RIDLER, T., AND S. CALVARD. 1978. Picture thresholding using an iterative selection method. IEEE Transactions on Systems, Man and Cybernetics 8: 630-632.

\title{
Prevalence of Agglutinating Antibodies to Sarcocystis neurona in Raccoons (Procyon lotor) From an Urban Area of Virginia
}

\begin{abstract}
Katie Hancock, Anne M. Zajac, Francois Elvinger ${ }^{\star}$, and David S. Lindsay + , Center for Molecular Medicine and Infectious Diseases, Department of Biomedical Sciences and Pathobiology, Virginia-Maryland Regional College of Veterinary Medicine, Virginia Tech, 1410 Prices Fork Road, Blacksburg, Virginia 24061-0342; *Department of Large Animal Clinical Sciences, Virginia-Maryland Regional College of Veterinary Medicine, Virginia Tech, 1410 Prices Fork Road, Blacksburg, Virginia 24061-0342; †To whom correspondence should be addressed. e-mail: lindsayd@vt.edu
\end{abstract}

\begin{abstract}
Equine protozoal myeloencephalitis is the most important protozoan disease of horses in North America and is usually caused by Sarcocystis neurona. Natural and experimentally induced cases of encephalitis caused by $S$. neurona have been reported in raccoons (Procyon lotor) and raccoons are an intermediate host for this parasite. A 3-yr-long serological survey was conducted to determine the prevalence of agglutinating antibodies to S. neurona in raccoons collected from Fairfax County, Virginia, a suburban-urban area outside Washington, D.C. Samples from 469 raccoons were examined, and agglutinating antibodies ( $\geq 1: 50$ dilution) were found in $433(92.3 \%)$ of the raccoons. This study indicates that exposure to $S$. neurona is high in this metropolitan area.
\end{abstract}

Equine protozoal myeloencephalitis is a neurologic disease in horses from the Americas and is usually caused by infection with the apicomplexan parasite Sarcocystis neurona (Dubey et al., 1991). It is the most important protozoan disease of horses in North America (reviewed by Dubey, Lindsay, Saville et al., 2001). The Virginia opossum Didelphis virginiana is the only known definitive host in North America (Dubey and Lindsay, 1998), whereas Didelphis albiventris is a host in South America (Dubey, Lindsay, Kerber et al., 2001). Nine-banded armadillos (Dasypus novemcinctus), raccoons (Procyon lotor), and sea otters (Enhydra lutris) are natural intermediate hosts (Cheadle, Tanhauser et al., 2001; Dubey, Rosypal et al., 2001; Dubey, Saville et al., 2001; Tanhauser et al., 2001). Domestic cats (Felis domesticus), striped skunks (Mephitis mephitis), and raccoons are known experimental intermediate hosts (Dubey et al., 2000; Cheadle, Yowell et al., 2001; Dubey, Saville et al., 2001).

Dubey, Saville et al. (2001) reported clinical encephalitis in experimentally infected raccoons. Stanek et al. (2002) described the life cycle of $S$. neurona in experimentally infected raccoons.

This study was conducted to determine the serological prevalence of antibodies to $S$. neurona in a common intermediate host, the raccoon. The direct $S$. neurona agglutination test (SAT) described by Lindsay and Dubey (2001) was used.

Raccoons originated in various locations in Fairfax County, Virginia, a suburban-urban area outside Washington, D.C. Raccoons used for this study were livetrapped as part of a larger study on rabies in Fairfax County. Blood samples were collected from all trapped raccoons. Rac- coons were released immediately after sampling was completed. The serum was collected, placed in a tube, and frozen at $-70 \mathrm{C}$. Frozen sera were sent to the Center for Molecular Medicine and Infectious Diseases, Department of Biomedical Sciences and Pathobiology, Virginia-Maryland Regional College of Veterinary Medicine, Virginia Tech, Blacksburg, Virginia for agglutination testing. Samples from 137, 120 , and 212 raccoons from 2000, 2001, and 2002, respectively, were examined (total $=469$ for $3 \mathrm{yr}$ ). The SAT was used to test sera at dilutions of 1:50. The SAT has previously been validated using sera from experimentally infected raccoons (Dubey, Saville et al., 2001; Lindsay et al., 2001; Stanek et al., 2002).

The prevalence of antibodies in 2000 was $128(93.4 \%)$ of the 137 samples, in 2001 it was $109(90.8 \%)$ of 120 samples, and in 2002 it was $196(92.5 \%)$ of 212 samples. The total prevalence of antibodies in the 469 raccoons was $93.3 \%(\mathrm{~N}=433$ positives $)$.

This study is the largest conducted to date on the prevalence of $S$. neurona antibodies in raccoons. Mitchell et al. (2002) examined sera from 12 raccoons from Connecticut and found that all 12 were positive in the SAT. Lindsay et al. (2001) demonstrated that sera from $33 \%$ of raccoons $(n=24)$ from Florida, $72 \%$ of raccoons $(n=25)$ from New Jersey, $52 \%$ of raccoons $(n=25)$ from Pennsylvania, and $96 \%$ of raccoons $(\mathrm{n}=25)$ from Massachusetts were positive in the SAT.

Clinical Sarcocystis sp.-associated encephalitis and myocarditis are common in raccoons (Stoffregen and Dubey, 1991; Thulin et al., 1992; Dubey, Hamir et al., 1990; Hamir and Dubey, 2001). These animals are often coinfected with canine distemper (Stoffregen and Dubey, 1992; Thulin et al., 1992). Experimental infection of raccoons with S. neurona is also potentially pathogenic for raccoons (Dubey, Saville et al., 2001; Stanek et al., 2002). Sarcocystis kirkpatricki is the only other named species of Sarcocystis infecting the muscles of raccoons (Snyder et al., 1990). Kirkpatrick et al. (1987) found sarcocysts in 26 (50\%) of 52 raccoons from Ohio, Pennsylvania, Florida, and Maryland. Snyder et al. (1990) found S. kirkpatricki sarcocysts in 66 of 100 raccoons examined from Illinois. Demonstration of sarcocysts in tissues is not as accurate as acid-pepsin digestion of tissues or serological methods, and this method usually underestimates prevalence. The life cycle of $S$. kirkpatricki is not known. Molecular studies are needed to determine the taxonomic relationship between $S$. neurona and S. kirkpatricki. 
Supported in part by Animal Health and Disease grant 137180 to D.S.L.

\section{LITERATURE CITED}

Cheadle, M. A., S. M. Tanhauser, J. B. Dame, D. C. Sellon, D. Hines, P. E. Ginn, R. J. MacKay, and E. C. Greiner. 2001. The ninebanded armadillo (Dasypus novemcinctus) is an intermediate host for Sarcocystis neurona. International Journal for Parasitology 31: 330-335.

, C. A. Yowell, D. C. Sellon, M. Hines, P. E. Ginn, A. E. Marsh, J. B. DAme, And E. C. Greiner. 2001. The striped skunk (Mephitis mephitis) is an intermediate host for Sarcocystis neurona. International Journal for Parasitology 31: 843-849.

Dubey, J. P., AND D. S. LindSAY. 1998. Isolation of Sarcocystis neurona from opossum (Didelphis virginiana) faeces in immunodeficient mice and its differentiation from Sarcocystis falcatula. International Journal for Parasitology 28: 1823-1828.

, S. W. Davis, C. A. Speer, D. D. Bowman, A. De Lahunta, D. E. Granstrom, M. J. Topper, A. N. Hamir, and M. M. Suter. 1991. Sarcocystis neurona n. sp. (Protozoa: Apicomplexa), the etiologic agent of equine protozoal myeloencephalitis. Journal of Parasitology 77: 212-218.

, A. N. Hamir, C. A. Hanlon, M. J. Topper, and C. E. RupPRECHT. 1990. Fatal necrotizing encephalitis in a raccoon associated with a Sarcocystis-like protozoon. Journal of Veterinary Diagnostic Investigation 2: 345-347.

, D. S. Lindsay, C. E. Kerber, N. Kasai, H. F. T. Pena, O. C H. KwoK, S. K. Shen, And B. M. Rosenthal. 2001. First isolation of Sarcocystis neurona from the South American opossum, Didelphis albiventris, from Brazil. Veterinary Parasitology 95: 295-304.

- D. S. Lindsay, W. J. A. SAville, S. M. Reed, D. E. GranSTROM, AND C. A. SPEER. 2001. A review of Sarcocystis neurona and equine protozoal myeloencephalitis (EPM). Veterinary Parasitology 95: 89-132.

- A. C. Rosypal, B. M. Rosenthal, N. J. Thomas, D. S. LindSay, J. F. Stanek, W. J. A. Saville, and S. M. Reed. 2001. Sarcocystis neurona infections in Sea otters (Enhydra lutris nereis): Evidence for natural infections with sarcocysts and transmission of infection to opossums (Didelphis virginiana). Journal of Parasitology 87: 1387-1393.

, W. J. A. Saville, D. S. Lindsay, R. W. Stich, J. F. Stanek, C. A. Speer, B. M. Rosenthal, C. J. Nuoku, S. K. Shen, and S M. REED. 2000. Completion of the life cycle of Sarcocystis neurona. Journal of Parasitology 86: 1276-1280.

, W. J. A. Saville, J. F. Stanek, D. S. Lindsay, B. M. Rosenthal, M. Olglesbee, A. C. Rosypal, C. J. Nuoku, R. W. Stich, O.
C. H. Kwok, S. K. Shen, A. N. Hamir, And S. M. Reed. 2001 Sarcocystis neurona infections in raccoons (Procyon lotor): Evidence for natural infection with sarcocysts, transmission of infection to opossums (Didelphis virginiana), and experimental induction of neurologic disease in raccoons. Veterinary Parasitology 100: $117-129$.

Hamir, A. N., And J. P. Dubey. 2001. Myocarditis and encephalitis associated with Sarcocystis neurona infection in raccoons (Procyon lotor). Veterinary Parasitology 95: 335-340.

Kirkpatrick, C. E., A. N. Hamir, J. P. Dubey, and C. E. Rupprecht 1987. Sarcocystis in muscles of raccoons (Procyon lotor L.). Journal of Protozoology 34: 445-447.

Lindsay, D. S., AND J. P. Dubey. 2001. Direct agglutination test for the detection of antibodies to Sarcocystis neurona in experimentally infected animals. Veterinary Parasitology 95: 179-186.

- A. C. Rosypal, J. A. Spencer, M. A. Cheadle, A. M. Zajac, C. Rupprecht, J. P. Dubey, And B. L. Blagburn. 2001. Prevalence of agglutinating antibodies to Sarcocystis neurona in raccoons, Procyon lotor, from the United States. Veterinary Parasitology 100: 131-134.

Mitchell, S. M., D. J. Richardson, M. A. Cheadle, A. M. Zajac, And D. S. LiNDSAY. 2002. Prevalence of agglutinating antibodies to Sarcocystis neurona in skunks (Mephitis mephitis), raccoons, (Procyon lotor), and opossums (Didelphis virginiana) from Connecticut. Journal of Parasitology 88: 1027-1029.

Snyder, D. E., G. C. SAnderson, M. Toivio-Kinnucan, and B. L. Blagburn. 1990. Sarcocystis kirkpatricki n. sp. (Apicomplexa: Sarcocystidae) in muscles of raccoons (Procyon lotor) from Illinois. Journal of Parasitology 76: 495-500.

StaneK, J. F., J. P. Dubey, M. J. Oglesbee, S. M. Reed, D. S. Lindsay, L. A. Capitini, C. J. Nuoku, K. L. Vittitow, and W. J. A. Saville. 2002. Life cycle of Sarcocystis neurona in its natural intermediate host, the raccoon, Procyon lotor. Journal of Parasitology 88: 11511158.

Stoffregen, D. A., And J. P. Dubey. 1991. A Sarcocystis sp.-like protozoan and concurrent canine distemper virus infection associated with encephalitis in a raccoon (Procyon lotor). Journal of Wildlife Disease 27: 688-692.

Tanhauser, S. M., M. A. Cheadle, E. T. Massey, B. A. Mayer, D. E. Schroedter, J. B. Dame, E. C. Greiner, and R. J. MacKay. 2001 The nine-banded armadillo (Dasypus novemcinctus) is naturally infected with Sarcocystis neurona. International Journal for Parasitology 31: 325-329.

Thulin, J. D., D. E. Granstrom, H. B. Gelberg, D. G. Morton, R. A. FRENCH, AND R. C. GILES. 1992. Concurrent protozoal encephalitis and canine distemper virus infection in a raccoon (Procyon lotor). Veterinary Record 130: 162-164.

\section{Parvicapsula minibicornis in Anadromous Sockeye (Oncorhynchus nerka) and Coho (Oncorhynchus kisutch) Salmon From Tributaries of the Columbia River}

Simon Jones, Gina Prosperi-Porta, Sheila Dawe, Kimberley Taylor, and Benjamin Goh, Department of Fisheries and Oceans, Pacific Biological Station, 3190 Hammond Bay Road, Nanaimo, British Columbia, V9T 6N7 Canada. e-mail: joness@pac.dfo-mpo.gc.ca

ABSTRACT: The myxosporean parasite Parvicapsula minibicornis is described from adult sockeye and coho salmon during spawning migrations in tributaries of the Columbia River in Canada and the United States. These observations extend the known distribution of this parasite from the Fraser River drainage basin. The parasite was identified in Columbia River salmonids using polymerase chain reaction (PCR) and by in situ hybridization, but unlike in Fraser River salmon, it was not observed in conventional histological preparations of the kidney. Prevalence of the parasite determined by PCR was higher in spawning sockeye from the Fraser River than in those from the Okanagan River. Our ability to explain the relatively low prevalence and absence of clinica
P. minibicornis infections in Columbia River salmon is hampered by our poor understanding of the life cycle of this parasite.

The myxosporean parasite Parvicapsula minibicornis was first described from the kidney of adult sockeye salmon (Oncorhynchus nerka) spawning at Weaver Creek, a tributary of the Fraser River in British Columbia, Canada (Kent et al., 1997). Pathological changes of the kidney were associated with $P$. minibicornis (Raverty et al., 2000; StHilaire et al., 2002), suggesting that severe infections may contribute to prespawn mortality observed among prematurely migrating sockeye 